\title{
Inhalation of ambroxol inhibits cigarette smoke-induced acute lung injury in a mouse model by inhibiting the Erk pathway
}

Ling-tian Ge ${ }^{\mathrm{a}, \mathrm{b}, \dagger}$, Ya-nan Liu ${ }^{\mathrm{a}, \mathrm{b}, \dagger}, \mathrm{Xi}^{-x i}$ Lin $^{\mathrm{b}}$, Hui-juan Shen ${ }^{\mathrm{b}}$, Yong-liang Jia ${ }^{\mathrm{b}}$, Xin-wei Dong ${ }^{\mathrm{b}}$, Yun Sun ${ }^{\mathrm{a},}$, Qiang-min Xie $\mathrm{Xic}^{\mathrm{b}, \mathrm{c} \text { * }}$

${ }^{a}$ Medical College of Yangzhou University, 11 Huaihai Road, Yangzhou City, Jiangsu Province, 225001, China

${ }^{\mathrm{b}}$ Zhejiang Respiratory Drugs Research Laboratory of China Food and Drug Administration, Medical Science College of Zhejiang University, Hangzhou 310058, China

${ }^{\mathrm{c}}$ Laboratory Animal Center of Zhejiang University, Hangzhou 310058, China

${ }^{\dagger}$ These authors contributed equally to this work.

* Corresponding authors at:

a. Yun Sun, Medical College, Yangzhou University, 11 Huaihai Road, Yangzhou 225001, Jiangsu Province, China. E-mail: jgz7718@ sina.com.

b. Qiang-min Xie, Zhejiang University School of Medicine, \# 866 Yuhangtang Rd., Hangzhou 310058, China. E-mail: xieqm@zju.edu.cn; Tel: +86 5718820 8231, Fax: +86 57188208070 


\begin{abstract}
Oral and injection administration of ambroxol has been clinically used to treat airway disease. However, little is known about its potentials in inhalation therapy. In present studies, we tested the effects of ambroxol by inhalation with intravenous administration, and explored the underlying working mechanism. The mice received 10 cigarettes exposure every day for 4 days. Inhaled solution of ambroxol was aerosolized $20 \mathrm{~min}$ before the exposure of cigarette smoke (CS). The effect of ambroxol on the expression of mucoprotein 5AC (MUC5AC) and proinflammatory cytokines in NCI-H292 cells stimulated with cigarette smoke extract (CSE). Four days of daily inhalation of ambroxol at 3.75 or $7.5 \mathrm{mg} / \mathrm{ml}$ for $20 \mathrm{~min}$ suppressed the accumulation of neutrophils and macrophages in the bronchoalveolar lavage fluid (BALF) and lung tissues, and inhibited increases in the mRNA and protein levels of tumor necrosis factor (TNF)- $\alpha$, CCL-2 and KC, but not interleukin (IL)- $1 \beta$ in the CS-exposed mice. Moreover, ambroxol at 3.75 or $7.5 \mathrm{mg} / \mathrm{ml}$ facilitated airway mucosa cilia clearance, reduced glycosaminoglycans level in BALF and MUC5AC mRNA levels in lung tissues. The effects of ambroxol by inhalation at $7.5 \mathrm{mg} / \mathrm{ml}$ was comparable to that of ambroxol at $20 \mathrm{mg} / \mathrm{kg}$ i.v. and dexamethasone at $0.5 \mathrm{mg} / \mathrm{kg}$ i.p. Using cultured lung epithelial cells, we demonstrated that pretreatment with ambroxol at 2 or $20 \mu \mathrm{M}$ inhibited the CSE-induced up-regulation of MUC5AC, TNF- $\alpha$, IL-1 $\beta$ mRNA levels, which was through inhibiting Erk signaling pathway. Our results demonstrate the beneficial effects of ambroxol as an inhalation replace systemic administration for COPD therapy.
\end{abstract}

Keywords: Ambroxol; Drug delivery; Mucokinetic activity; Airway inflammation 


\section{Introduction}

Chronic obstructive pulmonary disease (COPD) remains a major public health problem. The World Bank/World Health Organization reported that COPD will rank fifth worldwide based on the disease burden in 2020 [1]. According to the global initiative for COPD guidelines, COPD is recognized as an inflammatory disease state that includes increases in the levels of a complex cascade of inflammatory mediators, such as tumor necrosis factor- $\alpha(\mathrm{TNF}-\alpha)$, monocyte chemotactic protein (MCP-1 or CCL-2), interleukin-1 $\beta$ (IL-1 $\beta$ ) and IL-8 [2]. Cigarette smoke (CS) is a complex mixture of oxidant radicals and different chemical compounds, including reactive aldehydes and semiquinones that are known to cause oxidative stress in the lungs. CS exerts major effects on human health and is widely recognized as a primary risk factor associated with the progression of COPD.

Smoking and its associated tissue damage give rise to inflammation with an increase in the sequestration of neutrophils and inflammatory cells, resulting in the activation of redox-sensitive transcription factors, which are critical for the transcription of pro-inflammatory genes, including CCL-2, keratinocyte chemo-attractant (KC or mouse IL-8), IL-1 $\beta$ and TNF- $\alpha$ [3-5]. Indeed, CS leads to oxidative stress, high sputum secretion, small airway fibrosis, emphysema, and progressive airflow limitation [6,7]. It is believed that steroid treatment is primarily resisted by cigarette smoking patients with COPD, which indicates the urgent needs for efficient treatments [8].

Ambroxol (Amb, 2-amino-3,5-dibromo-N-[trans-4-hydroxycyclohexyl] benzylamine) is a metabolite of bromhexine. Both bromhexine (Bisolvon) and Amb are semisynthetic derivatives of vasicine, used in the treatment of respiratory disorders with productive cough. Its major pharmacodynamic actions are surfactant stimulation, mucokinetic and secretagogue activity [9]. In addition to a mucolytic action, Amb has antioxidant and anti-inflammatory properties in vitro [10-14] and in vivo [15-17]. Amb has been proposed to treat chronic pulmonary disorders, such as COPD [18-20], acute lung injury/acute respiratory distress syndrome [21-23], 
idiopathic pulmonary fibrosis [24-26] and upper respiratory disease [27]. Amb significantly reduced the lung hemorrhage, edema, exudation, neutrophil infiltration, the histological score of lung injury and the cytokine levels in a murine model of lipopolysaccharide-induced lung injury [17]. In another study, Amb enhanced LPS-induced secretion of IL-12 and the ratio of IL-12/IL-10, which suggests that Amb appears to strengthen innate immune response and cell-mediated immunity, and facilitate the development of Th-1 cells [28]. The effects of Amb on the release of histamine, leukotrienes, cytokines and superoxide anions from a variety of cells involved in the pathogenesis of allergic reaction and inflammation [14]. Amb can inhibit the release of mediators of allergic reaction from mast cells and leukocytes, which make it potent in the treatment of allergic and inflammatory respiratory diseases.

In clinical drug delivery, in general, oral or injection administration of Amb is the most commonly used method for airway disease. However, little is known about its potentials as an inhalation (i.h) therapy to treat CS-induced mucous hypersecretion and inflammatory responses. In this study, we hypothesize that Amb is a potential anti-inflammatory drug exerting biological and pharmacokinetic properties suitable for delivery by inhalation. Inhalation of Amb may overcome low clinical efficacy, and weaken the side effects from oral administration or injection. We aimed to investigate whether the inhalation of Amb could inhibit pathological changes in a rodent model of CS-induced acute lung injury, as well as in cigarette smoke extract (CSE)-exposed lung epithelial cells. We intended to explicit the beneficial effects of Amb in inhalation therapy for COPD.

\section{Materials and methods}

\subsection{Animals}

Female ICR mice (weighing $22 \pm 2.5 \mathrm{~g}$ ) were purchased from Shanghai Slac Laboratory Animal Co. Ltd. (No. SCXK 2012-0002). The animals were housed in isolated ventilated cages (4-5 mice/cage) under a 12-h light/12-h dark cycle and received food and water ad libitum in the Laboratory Animal Center of Zhejiang 
University. All of the animal experiments performed in this study were approved by the Institutional Animal Care and Use Committee of Zhejiang University School of Medicine.

\subsection{Drug administration}

The inhaled solution of ambroxol hydrochloride (Amb, $15 \mathrm{mg} / 2 \mathrm{ml}$, Tianjin Institute of Pharmaceutical Research., Tianjin, China) for inhalation was prepared at concentrations of $1.875,3.75$, and $7.5 \mathrm{mg} / \mathrm{ml}$. Then, Inhaled solution of Amb was aerosolized for 20 min with a jet nebulizer (BARI Co. Ltd., Germany) 20 min before the exposure of the animals to cigarettes. The plasma concentrations of 1.875, 3.75, and $7.5 \mathrm{mg} / \mathrm{ml}$ by i.h for $20 \mathrm{~min}$ are the dose equivalent of intravenous injection (i.v.) of $0.7,1.34,2.78 \mathrm{mg} / \mathrm{kg}$, which are measured by HPLC. As a reference drug, Amb hydrochloride injection (15 mg/2 ml, Tianjin Institute of Pharmaceutical Research., Tianjin, China) $20 \mathrm{mg} / \mathrm{kg}$ was injected by i.v. $10 \mathrm{~min}$ before their exposure to cigarettes. As a positive control drug, dexamethasone sodium phosphate (Tianjin Jin Yao Group Hubei Tianyao Pharmaceutical Co., LTD) at $0.5 \mathrm{mg} / \mathrm{kg}$ was intraperitoneally (i.p.) injected into mice $1 \mathrm{~h}$ before their exposure to cigarettes. The control and model mice received solvent inhalation.

\subsection{Cigarette exposure}

The mice were exposed to whole-body CS generated from research grade cigarettes (3R4F; University of Kentucky, Lexington, KY, USA) in a square plastic box $(45 \times 45 \times 20 \mathrm{~cm})$ once a day for 4 days as described previously [29-31]. The mice were exposed to seven cigarettes on the first day, nine cigarettes on the second day, and 11 cigarettes on both the third and fourth days. Lung tissues and bronchoalveolar lavage fluid (BALF) were collected $18 \mathrm{~h}$ after the last CS exposure. The control animals were exposed to room air.

\subsection{Preparation of bronchoalveolar lavage fluids}

Eighteen hours after the last CS exposure, the mice were euthanized through an i.p. pentobarbital injection of $6 \mathrm{~g} / \mathrm{kg}$ urethane. The BALF was obtained by cannulating the trachea and lavaging with PBS containing 1\% BSA and 5000 IU/l heparin. The BALF cells were centrifuged once at $500 \mathrm{~g}$ and $4{ }^{\circ} \mathrm{C}$ for 10 min with PBS containing $2 \%$ 
FCS. The pelleted BALF cells were resuspended in PBS, and the total number of leukocytes was counted using a Neubauer chamber. A total of 200 cells in a cytocentrifuged preparation of BALF stained with Wright-Giemsa were differentiated under a light microscope according to the classical cell morphology. The total number of each cell type was determined by multiplying the percentage by the total number of cells. The results were expressed as the number of each cell population in $1 \mathrm{ml}$ of BALF.

\subsection{Tissue processing and histological analysis}

With the mice under terminal anesthesia, the left lungs were removed, infused with $10 \%$ formalin, and immersed in the same solution, and the tissue was then processed in paraffin-embedded blocks. The sections were stained with H\&E to evaluate the general morphology. To determine cell counts in the alveolar spaces and severity of the infiltration of the inflammatory cells were performed based on the 5-point scoring system described in our previous papers [32, 33]. The analyses were performed in a blind fashion, and the slides were presented in a random order for each examination.

\subsection{Mucociliary clearance and glycosaminoglycans level in CS-exposed mice}

Mucociliary clearance in CS-exposed mice were performed according to the report of Hosoe and colleagues [34]. Under pentobarbital anesthesia (45 mg/kg, i.p.), the carbon solution was instilled to evaluate the mucociliary clearance $30 \mathrm{~min}$ after CS exposed mice. BALF was performed $2 \mathrm{~h}$ after carbon instillation and the OD value of BALF was determined. Drugs pretreatment were administered to see the section 2.2.drug administration. The glycosaminoglycans concentration in BALF was estimated according to the report of Goldberg and Kolbas [35].

\subsection{RNA isolation and quantitative PCR}

To investigate the effects of Amb on IL-1 $\beta$, TNF- $\alpha$, CCL-2, and KC as well as mucoprotein 5AC (MUC5AC) mRNA expression in the lung tissues and pulmonary epithelial cells, the mice inhaled Amb $7.5 \mathrm{mg} / \mathrm{ml} 20 \mathrm{~min}$ before CS exposure or Amb pretreated epithelial cells, and the lung tissues were obtained $18 \mathrm{~h}$ after the final CS or 
epithelial cells were obtained $24 \mathrm{~h}$ after cigarette smoke extract (CSE) exposed cells. The total RNA of lung tissue homogenates and epithelial cells were extracted with the TRIzol reagent (Takara Bio, Dalian, China) according to the manufacturer's instructions. The PCR primers were purchased from Shanghai Bioengineering (Shanghai, China). All of the primers were checked using a basic local alignment search tool to determine their selectivity. Real-time PCR cycling was conducted (7500 Real-Time PCR System; Applied Biosystems, Carlsbad, CA, USA) under the following conditions: the PCR mixture consisted of $10.4 \mu \mathrm{l}$ of SYBR GreenMasterMix, $0.4 \mu \mathrm{l}$ of both the sense and antisense primers, $2.0 \mu \mathrm{l}$ of the sample cDNA solution, and distilled water to obtain a final volume of $20 \mu 1$. The program for chymase was conducted as follows: a denaturation step at $95^{\circ} \mathrm{C}$ for $40 \mathrm{~s}$ and 40 cycles of $95{ }^{\circ} \mathrm{C}$ for $10 \mathrm{~s}, 58{ }^{\circ} \mathrm{C}$ for $10 \mathrm{~s}$, and $72{ }^{\circ} \mathrm{C}$ for $34 \mathrm{~s}$. The primer sequences are described in Table 1, and $\beta$-actin was used as an internal control.

\subsection{Enzyme-linked immunosorbent assay (ELISA)}

To investigate the effects of Amb on IL-1 $\beta$, TNF- $\alpha$, CCL-2, and KC cytokines protein expression as well as MUC5AC protein expression in the BALF, the BALF were analyzed using ELISA kits (Boster, Wuhang, China and Jiancheng Bioengineering Institute, Nanjing, Jiangsu Province, China) according to the manufacturer's

\subsection{Cell culture}

NCI-H292 cells, a human pulmonary epithelial cell line, were obtained from the Cell Bank, Chinese Academy of Sciences. The cells were maintained in RPMI 1640 (HyClone, Logan, UT) containing $10 \% \mathrm{FBS}$ (HyClone) at $37^{\circ} \mathrm{C}$ in the presence of $5 \%$ $\mathrm{CO}_{2}$

\subsection{Preparation of cigarette smoke extract (CSE)}

Research-grade cigarettes (3R4F) were obtained from the Kentucky Tobacco Research Council (University of Kentucky). The composition of 3R4F research-grade cigarettes was as follows: total particulate matter, $10.9 \mathrm{mg}$ per cigarette; tar, $9.4 \mathrm{mg}$ per cigarette; and nicotine, $0.726 \mathrm{mg}$ per cigarette. CSE was prepared by bubbling smoke from three cigarettes into $30 \mathrm{ml}$ PBS, modifying the method used in previous 
research. CSE was standardized by measuring the absorbance at a wavelength of 320 $\mathrm{nm}$. After filtering through a $0.45-\mu \mathrm{M}$ filter, CSE was frozen in aliquots and stored at $-80^{\circ} \mathrm{C}$. An aliquot of CSE was thawed immediately before use [29].

\subsection{Immunoblotting analysis}

NCI-H292 cells were seeded into a six-well plate. After reaching the confluent, the cells were incubated in serum-free medium (RPMI 1640) overnight and then exposed to CSE in the presence or absence of PHPS1 for $15 \mathrm{~min}$. After treatment, the cells were washed three times with ice-cold PBS and lysed in $100 \mu 1$ radioimmunoprecipitation assay buffer with 10 mM PMSF (Beyotime, Haimen, China). The protein concentration was measured by the BCA Protein Assay Kit (cwbiotech, Beijing, China). A sample of protein $(20-50 \mu \mathrm{g})$ from the cell lysates was separated by SDS-PAGE in $12 \%$ polyacrylamide gel and transferred to nitrocellulose membranes (Pall, Port Washington, NY), which were blocked with 5\% fat-free milk ( $1 \mathrm{~h}$ at room temperature). The membranes were then incubated with $\mathrm{p}$-Erk and p-P38, Erk and P38 (Cell Signaling Technology) and actin primary Abs (Bioworld, St. Louis Park, MN). Afterward, the membranes were rinsed with TBST and then probed with secondary Abs (Invitrogen) for $1 \mathrm{~h}$ at room temperature. Immunoreactive bands were visualized by a two-color infrared imaging system (Odyssey; LI-COR, Lincoln, NE).

\subsection{Statistical analysis}

The data are expressed as the means \pm S.E.M. The statistical tests were performed using the SPSS software (version 16.0; SPSS, Chicago, IL, USA). One-way ANOVA followed by the Student-Newman-Keuls test was used for the multiple comparisons. Statistical significance was accepted at $P<0.05$.

\section{Results}

\subsection{Ambroxol alleviates CS-induced lung inflammation in mice}

To evaluate the effects of Amb on CS-induced pulmonary inflammation, the infiltrated inflammatory cells were counted following four days of CS exposure. In the BALF, CS exposure resulted in increased numbers of total inflammatory cells, neutrophils, macrophages, and lymphocytes compared with the control $(P<0.001)$ 
(Fig. 1A). Twenty min inhalation of Amb at 1.875, 3.75, and $7.5 \mathrm{mg} / \mathrm{ml} 20 \mathrm{~min}$ before mice was exposed to CS concentration-dependently inhibited the CS-induced inflammatory cell accumulation, including total leukocytes, neutrophils and macrophages in the BALF. The lung sections were further histologically analyzed. As illustrated in Fig. 1B, C, H\&E staining revealed that Amb inhalation, compared with CS exposure alone, alleviated the infiltration of neutrophils and macrophages into the alveolar spaces. Amb at $7.5 \mathrm{mg} / \mathrm{ml}$ by aerosol seems to be more potent than that of $\mathrm{Amb}$ at $20 \mathrm{mg} / \mathrm{kg}$ by i.v. administration in Fig. $1 \mathrm{C}(\mathrm{p}<0.05)$. Dex at a dose of 0.5 $\mathrm{mg} / \mathrm{kg}$, as a positive reference drug, also showed significant inhibitory effects on the accumulation of inflammatory cell. These observations reveal a potent role of Amb inhalation in reducing the recruitment of inflammatory cells in acute mouse models of CS.

\subsection{Ambroxol reduces $m R N A$ levels of $I L-1 \beta, T N F-\alpha, C C L-2$ and $K C$ in the lung} tissues and their protein levels in the BALF

To measure the IL-1 $\beta$, TNF- $\alpha$, CCL-2 and KC mRNA expression and protein level, the lung tissues and the BALF were harvested and examined $18 \mathrm{~h}$ after the final CS exposure. As shown in Fig.2A and B, the CS-exposed mice showed a significant up-regulation in the IL-1 $\beta$, TNF- $\alpha$, CCL- 2 and KC mRNA and protein levels compared to the control mice, which were all significantly reduced by the aerosol pretreatment with Amb at 1.875, 3.75, or $7.5 \mathrm{mg} / \mathrm{ml}$ in a dose-dependent manner, except the IL-1 $\beta$ mRNA expression. The inhibitory effects of Amb at $7.5 \mathrm{mg} / \mathrm{ml}$ i.h. were comparable to that of Dex at $0.5 \mathrm{mg} / \mathrm{kg}$ i.p. Moreover, the inhibitory effect of Amb at $3.75 \mathrm{mg} / \mathrm{ml}$ i.h. on TNF- $\alpha$ and $\mathrm{KC}$ protein expression are more potent than that of Amb at $20 \mathrm{mg} / \mathrm{kg}$ by i.v. administration in Fig. $2 \mathrm{~B}(\mathrm{p}<0.05)$.

\subsection{Ambroxol increases the clearance function of airway mucosa cilia and decreases} mRNA expression of MUC5AC in the lung tissues and glycosaminoglycans in the $B A L F$.

To measure the clearance function of airway mucosa cilia, glycosaminoglycans level, MUC5AC mRNA and protein expression and in vivo, the BALF and the lung tissues were harvested and examined after the final CS exposure. As shown in Fig.3A, 
$\mathrm{B}, \mathrm{C}$ and D, the CS-exposed mice significantly decreased the clearance function of airway mucosa cilia, up-regulated glycosaminoglycans levels and MUC5AC mRNA and protein expression. Amb dose-dependently enhanced the clearance function of airway mucosa cilia, normalized the glycosaminoglycans levels in BALF as well as the MUC5AC mRNA and protein levels in lung tissues in the CS-exposed mice. Importantly, the effects of $\mathrm{Amb}$ at $3.75 \mathrm{mg} / \mathrm{ml}$ i.h. on inhibiting glycosaminoglycans levels in the BALF were comparable to that of Amb at $20 \mathrm{mg} / \mathrm{ml}$ i.v. and Dex at $0.5 \mathrm{mg} / \mathrm{kg}$ i.p.

\subsection{Ambroxol suppresses the CSE-induced IL-1 $\beta$, TNF- $\alpha$ and MUC5AC mRNA} expression in the pulmonary epithelial cells

To examine the effects of CSE on IL- $1 \beta$, TNF- $\alpha$ and MUC5AC mRNA expression in lung epithelia, pulmonary epithelial cells were treated with CSE at different concentration with various duration, then followed by measures of IL-1 $\beta$, TNF- $\alpha$ and MUC5AC mRNA expression. We found remarkable elevations of IL-1 $\beta$, TNF- $\alpha$ and MUC5AC in lung epithelial cells with CSE exposure that were in a concentration- and time-dependent manner (Fig. 4 A and B). Amb $20 \mu \mathrm{M}$ significantly decreased the CSE-mediated IL-1 $\beta$, TNF- $\alpha$ and MUC5AC mRNA expression (Fig. 4 C).

\subsection{Ambroxol inhibits the CSE-induced Erk1/2 activity}

We then further explored the molecular mechanisms of Amb in the expression of CS-induced inflammatory factors and MUC5AC. We found that CSE-induced Erk and P38 activation. Further, Erk activation, but not P38 activation was inhibited by Amb at $20 \mu \mathrm{M}$ (Fig. 5 A and B). Erk inhibitor - U0126 $10 \mu \mathrm{M}$ (Fig. 5C), but not p38 inhibitor - SB203580 (data not shown) significantly decreased the CSE-mediated IL-1 $\beta$, TNF- $\alpha$ and MUC5AC mRNA expression. Our data suggest that Amb decreased the CSE-induced Erk1/2 activation, which may explain part of the molecular mechanisms.

\section{Discussion}

In this article, we report that the inhalation of Amb prevents the CS-induced 
inflammatory responses in pulmonary epithelia via Erk signaling pathway. These findings extended our view regarding the improved potency of administrating drug through a novel route. Furthermore, the biological roles of Amb in the pathogenesis of pulmonary inflammation and mucolytic action were also extensively explicated. Although several articles have described the in vivo anti-inflammatory activity of ambroxol $[9,17]$, conclusion is still controversial. As Amb has activity to facilitate airway mucosa cilia clearance, its anti-inflammatory activity is possibly due to the reduction of the exposure of cigarette smoke extract or other inflammatory stimulants. Despite of the CS-induced lung injury model and our in vitro results, we suggest that the anti-inflammatory effects of Amb involve both the facilitation of airway mucosa cilia clearanceand its direct anti-inflammatory effects on other inflammatory stimulants, such as LPS [17], N-formyl-methionyl-leucyl-phenylalanine (FMLP) [12], concanavalin A and compound 48/80 [10], hydrogen peroxide [15] and doxorubicin [16].

Cigarette smoking is a leading cause of COPD, which is associated with persistent inflammatory responses and increased viscous sputum secretion [36, 37]. The lung inflammatory responses to CS exposure are more complex than the neutrophil accumulation, including high sputum secretion, small airway fibrosis and emphysema. We studied a novel delivery that is inhalation of Amb - a conventional drug for treating COPD. Amb is frequently used as a mucolytic agent in respiratory diseases associated with increased mucus production like acute or chronic bronchitis [18-20]. In addition to mucus regulatory effects, a wide range of pharmacological anti-inflammatory properties of ambroxol have been described in vitro and in vivo [9], including the inhibition or scavenging of oxidative and nitrosative stress, the increases in local defense molecules involved in respiratory virus replication, the reduction of pro-inflammatory cytokines and arachidonic acid metabolites, inflammatory cell chemotaxis, and lipid peroxidation of tissues [38, 39].

Ambroxol is marketed in various pharmaceutical formulations, including intravenous and intramuscular solutions, liquids, granules, tablets, capsules, suppositories and oral slow release formulations. Systemic administration of Amb 
requires substantially high dose and may be associated with a greater incidence of systemic side effects. On the other hand, the absorption of i.v. administration is faster than oral administration. But it also requires a substantially higher dose; thereby it may also increase systemic side effects and lead to poor patient compliance. Logically, the inhalation administration of Amb could overcome some of the drawbacks from the above delivery routes. Recently, Ren et al [40,41] reported that Amb DPI (dry powder inhalation) at $20 \mathrm{mg} / \mathrm{kg}$, given via tracheal administration (TA), achieved a high local concentration in lung epithelial lining fluid (ELF) and reached a maximum concentration $\left(\mathrm{C}_{\max }\right)$ at $1.5 \mathrm{~h}$ in plasma. After the same dose Amb was given by i.v., Amb reached a $\mathrm{C}_{\max }$ in ELF at $1.25 \mathrm{~h}$. The AUC (0-t) (ELF)/(AUC(0-t)) (plasma) ratio (1.05-2.25) after TA differed significantly from the ratio (0.029-0.039) observed after i.v. Amb $(p<0.05)$. Their results indicate that Amb DPI can be locally delivered to achieve high concentration in ELF. Therefore, the inhalation of Amb could be a useful drug delivery system for treating pulmonary diseases. In addition, a clinical literature described that the volume of distribution is 17 folds higher for dose deposition within the lung than within the plasma if Amb was administrated intratracheally [42]. These results suggest that the lung tissue and plasma concentration following i.v. administration of Amb was only $3 \%$ to $4 \%$ compared to that following i.h. or i.t. delivery administration. However, in rats, these values were $8 \%$ to $10 \%$, and a healthy volunteer study showed $55 \%$ to $60 \%$ increases in the pattern of deposition within the lung following a treatment with HFA-beclomethasone metered-dose inhaler [43]. As discussed above, these results suggest that Amb is a potential anti-inflammatory drug that has pharmacological and pharmacodynamic properties suitable for delivery via inhalation.

Although intragastric administration (i.g) and intraperitoneal administration (i.p) of Amb have shown good efficacy in preclinical models [15-17], it is not clear if i.h. administration of Amb influences the pro-inflammatory factors and mucolytic action. In the present study, i.h. administration of Amb significantly inhibited the CS-induced increases in the mRNA and protein levels of TNF- $\alpha$, IL-1 $\beta$, CCL-2 and KC in lung tissues and in the BALF. Moreover, Amb at a dose of 1.875, 3.75 and $7.5 \mathrm{mg} / \mathrm{ml}$ 
dose-dependently increased the clearance function of airway mucosa cilia, decreased glycosaminoglycans level in the BALF and MUC5AC mRNA levels in lung tissues in the CS-exposed mice. The inhalation of Amb 1.875, 3.75, and $7.5 \mathrm{mg} / \mathrm{ml}$ concentration-dependently inhibited CS-induced accumulation of inflammatory cells, including total leukocytes, neutrophils and macrophages in the BALF and the infiltration of neutrophils and macrophages within the alveolar spaces in lung tissues. Amb $7.5 \mathrm{mg} / \mathrm{ml}$ by i.h. administration was more potent than that of Amb $20 \mathrm{mg} / \mathrm{kg}$ by i.v. administration. In in vitro studies, we found that pretreatment with Amb 0.2, 2 and $20 \mu \mathrm{M}$ inhibited Erk signaling. Subsequentially, Amb concentration-dependently inhibited the CSE-induced increases in MUC5AC, TNF- $\alpha$, IL-1 $\beta$, CCl-2 mRNA levels in the epithelial cells.

Mucus hypersecretion is a distinguishing feature of COPD, which is defined physiologically by limitations of airflow and pathologically by repetitive injury and inappropriate epithelial repair in airways [44]. MUC5AC appears most frequently in studies of human secretions and is regulated by many mediators that are likely to be present in the airways of COPD patients. The increase of MUC5AC expression will lead high secretion of sputum, small airway fibrosis and progressive airflow limitation [44]. The studies with acrolein and cigarette smoke have suggested that MUC5AC is inducible (accompanied by epidermal growth factor (EGF) ligand formation and the activation of EGF receptor-dependent pathways) [45]. The prevalence of patient presentation with cough and expectoration of sputum and the perceived importance of mucus in the pathophysiology of COPD, have led to development of drugs intended to treat airway mucus hypersecretion [46]. Essentially, the associated pharmacotherapy divides into two sections. The first is anti-inflammatory treatment of airway inflammation, probably the most beneficial therapy overall. The second is therapies directed specifically at different aspects of the pathophysiology of mucus hypersecretion, from inhibition of the secretagogue effects of specific endogenous inflammatory secretagogues to aiding expectoration of sputum by use of mucolytics $[47,48]$. Amb is widely used in clinical practice, because it combines the effects of both anti-inflammatory and reducing mucus hypersecretion. 
Substantial evidences have been presented that the activation of Erk is involved in various inflammatory conditions. For example, D'Armiento laboratory demonstrated a rapid and long-lasting cigarette smoke-induced activation of Erk-1/2 MAP kinase in cultured pulmonary epithelial cells [49]. In addition, they also found the elevated phosphorylation of Erk-1/2 (p44/42) in the lungs in mice exposed to cigarette smoke for 10 days [49]. These results are consistent with ours. Most importantly, the relevance between these events and COPD was established by the discovery of a significantly elevated Erk-1/2 activity in airway and alveolar epithelial cells of patients with emphysema, compared with non-emphysematous controls [49]. Other studies reported an increased mRNA and protein expression of Egr-1, an Erk-1/2 substrates, in lung tissues of patients with emphysema, suggesting that the activation of Erk-1/2 signaling is involved in the pathogenesis [50]. It is also likely that the activation of different MAP kinases can induce the same transcription factor. For example, Erk-1/2 [51] and JNK pathways each have been shown to activate NF- $\kappa B$ signaling in human monocytes and airway epithelial cells [52], demonstrating the potentials for crosstalk between these pathways.

In summary, our results demonstrate that i.h. administration of Amb attenuates the CS-induced accumulation of inflammatory cells in the BALF, reduces the infiltration of neutrophils and macrophages into the alveolar spaces in lung tissues. Inhalation administration of Amb inhibits the mRNA expression or protein release of pro-inflammatory cytokines and decreases the glycosaminoglycans level in the BALF. It also down regulated the expression of MUC5AC mRNA in lung tissues in the CS-exposed mice. Moreover, Amb showed a concentration-dependent inhibition on the CSE-induced increases in MUC5AC, TNF- $\alpha$, IL-1 $\beta$ mRNA levels in epithelial cells by inhibiting Erk signaling pathway. Our results reviewed a beneficial effect of Amb with inhalation administration for treating COPD.

\section{Acknowledgements}

This work was supported by grants from the National Science Foundation of China (No. 81373224 and No. 81573439). 


\section{References}

[1] Global Initiative for Chronic Obstructive Lung Disease (GOLD). Global Strategy for the Diagnosis, Management and Prevention of COPD. Available rom: http://www.goldcopd.org/; 2013.

[2] Sethi S, Mahler DA, Marcus P, Owen CA, Yawn B, Rennard S. Inflammation in COPD: implications for management. Am J Med. 2012; 125:1162-1170.

[3] Taraseviciene-Stewart L, Voelkel NF. Molecular pathogenesis of emphysema. J Clin Invest. 2008; 118:394-402.

[4] Tuder RM, Petrache I. Pathogenesis of chronic obstructive pulmonary disease. J Clin Invest. 2012; 122:2749-2755.

[5] Yoshida T, Tuder RM. Pathobiology of cigarette smoke-induced chronic obstructive pulmonary disease. Physiol Rev. 2007; 87:1047-82.

[6] MacNee W. Oxidative stress and lung inflammation in airways disease. Eur J Pharmacol. 2001; 429:195-207.

[7] Rahman I, Biswas SK, Kode A. Oxidant and antioxidant balance in the airways and airway diseases. Eur J Pharmacol. 2006; 533:222-39.

[8] Adcock IM, Barnes PJ. Molecular mechanisms of corticosteroid resistance. Chest. 2008; 134:394-401.

[9] Disse BG. The pharmacology of ambroxol-review and new results. Eur J Respir Dis. 1987; 153(Suppl):255-262.

[10]Gillissen A, Bartling A, Schoen S, Schulte-Werninghaus G. Antioxidant function of ambroxol in mononuclear and polymorphonuclear cells in vitro. Lung. 1997; $175: 235-242$.

[11]Gillissen A, Schärling B, Jaworska M, Bartling A, Rasche K, Schulte-Werninghaus G. Oxidant scavenger function of ambroxol in vitro: a 
comparison with N-acetylcysteine. Res Exp Med. 1997; 196:386-398.

[12]Peroni DG, Moser S, Gallo G, Pigozzi R, Tenero L, Zanoni L, Boner AL, Piacentini GL. Ambroxol inhibits neutrophil respiratory burst activated by alpha chain integrin adhesion. Int J Immunopathol Pharmacol. 2013; 26:883-887.

[13] Nowak D, Antezak A, Krol M, Bialasiewicz P, Pietras T. Antioxidant properties of ambroxol. Free Radic Biol Med. 1994; 16:517-522.

[14]Gibbs BF, Schmutzler W, Vollrath IB, Brosthardt P, Braam U, Wolff HH, Zwadlo-Klarwasser G. Ambroxol inhibits the release of histamine, leukotrienes and cytokines from human leukocytes and mast cells. Inflamm Res. 1999; 48:86-93.

[15]Nowak D, Antezak A, Pietras T, Bialasiewicz P, Krol M. Protective effect of ambroxol against heat-and hydrogen peroxide-induced damage to lung lipids in mice. Eur Respir J. 1994; 7:1629-1634.

[16]Nowak D, Pierscinski G, Drzewoski J. Ambroxol inhibits doxorubicin-induced lipid peroxidation in heart of mice. Free Radic Biol Med. 1995; 19:659-663.

[17] Su X, Wang L, Song Y, Bai C. Inhibition of inflammatory responses by ambroxol,a mucolytic agent, in a murine model of acute lung injury induced by lipopolysaccharide. Intensive Care Med. 2004; 30:133-140.

[18] Malerba M, Ponticiello A, Radaeli A, Bensi G, Grassi V. Effect of twelve-months therapy with oral ambroxol in preventing exacerbations in patients with COPD. Double-blind, randomized, multicenter, placebo-controlled study (the AMETHIST Trial). Pulm Pharmacol Ther. 2004; 17:27-34.

[19]Gupta PR. Ambroxol - Resurgence of an old molecule as an anti-inflammatory agent in chronic obstructive airway diseases. Lung India. 2010; 27:46-48.

[20]Jahnz-Rózyk K, Kucharczyk A, Chciałowski A, Płusa T. The effect of inhaled ambroxol treatment on clinical symptoms and chosen parameters of ventilation in patients with exacerbation of chronic obstructive pulmonary disease patients. Pol Merkur Lekarski. 2001; 11:239-43.

[21]Wu X, Li S, Zhang J, Zhang Y, Han L, Deng Q, Wan X. Meta-analysis of high doses of ambroxol treatment for acute lung injury/acute respiratory distress 
syndrome based on randomized controlled trials. J Clin Pharmacol. 2014; 54:1199-1206.

[22]Zhang ZQ, Wu QQ, Huang XM, Lu H. Prevention of respiratory distress syndrome in preterm infants by antenatal ambroxol: a meta-analysis of randomized controlled trials. Am J Perinatol. 2013; 30:529-36.

[23] Gonzalez Garay AG, Reveiz L, Velasco Hidalgo L, Solis Galicia C. Ambroxol for women at risk of preterm birth for preventing neonatal respiratory distress syndrome. Cochrane Database Syst Rev. 2014; 10:CD009708.

[24]Gupta PR. Ambroxol hydrochloride in the management of idiopathic pulmonary fibrosis: Clinical trials are the need of the hour. Lung India. 2014; 31:43-46.

[25]Tam J, Nash EF, Ratjen F, Tullis E, Stephenson A. Nebulized and oral thiol derivatives for pulmonary disease in cystic fibrosis. Cochrane Database Syst Rev. 2013; 7:CD007168.

[26] Nash EF, Stephenson A, Ratjen F, Tullis E. Nebulized and oral thiol derivatives for pulmonary disease in cystic fibrosis. Cochrane Database Syst Rev. 2009; (1):CD007168.

[27] Nobata K, Fujimura M, Ishiura Y, Myou S, Nakao S. Ambroxol for the prevention of acute upper respiratory disease. Clin Exp Med. 2006; 6:79-83.

[28] Aihara M, Dobashi K, Akiyama M, Naruse I, Nakazawa T, Mori M. Effects of $\mathrm{N}$-acetylcysteine and ambroxol on the production of IL-12 and IL-10 in human alveolar macrophages. Respiration. 2000; 67:662-671.

[29]Li FF, Shen J, Shen HJ, Zhang X, Cao R, Zhang Y, Qui Q, Lin XX, Xie YC, Zhang LH, Jia YL, Dong XW, Jiang JX, Bao MJ, Zhang S, Ma WJ, Wu XM, Shen H, Xie QM, Ke Y. Shp2 plays an important role in acute cigarette smoke-mediated lung inflammation. J Immunol 2012; 189:3159-3167.

[30]Bao MJ, Shen J, Jia YL, Li FF, Ma WJ, Shen HJ, Shen LL, Lin XX, Zhang LH, Dong XW, Xie YC, Zhao YQ, Xie QM. Apple polyphenol protects against cigarette smoke-induced acute lung injury. Nutrition. 2013; 29:235-243.

[31] Shen HJ, Sun YH, Zhang SJ, Jiang JX, Dong XW, Jia YL, Shen J, Guan Y, Zhang LH, Li FF, Lin XX, Wu XM, Xie QM, Yan XF. Cigarette smoke-induced alveolar 
epithelial-mesenchymal transition is mediated by Rac1 activation. Biochim Biophys Acta. 2014; 1840:1838-49.

[32]Cao R, Dong XW, Jiang JX, Yan XF, He JS, Deng YM, Li FF, Bao MJ, Xie YC, Chen XP, Xie QM. M3 muscarinic receptor antagonist bencycloquidium bromide attenuates allergic airway inflammation, hyperresponsiveness and remodeling in mice. Eur J Pharmacol. 2011; 655:83-90.

[33]Xie QM, Wu X, Wu HM, Deng YM, Zhang SJ, Zhu JP, Dong XW. Oral administration of allergen extracts from Dermatophagoides farinae desensitizes specific allergen-induced inflammation and airway hyperresponsiveness in rats. Int Immunopharmacol. 2008; 8:1639-1645.

[34]Hosoe H, Kaise T, Ohmori K. Erdosteine enhances mucociliary clearance in rats with and without airway inflammation. J Pharmacol Toxicol Methods. 1998; 40:165-171.

[35] Goldberg RL, Kolbas LM. An improved method for determining proteoglycans synthesized by chondrocytes in culture. Conn Tissue Res. 1990; 24: 265-275.

[36] Yoshida T, Tuder RM. Pathobiology of cigarette smoke-induced chronic obstructive pulmonary disease. Physiol Rev. 2007; 87:1047-1082.

[37]Goldkorn T, Filosto S. Lung injury and cancer: mechanistic insights into ceramide and EGFR signaling under cigarette smoke. Am J Respir Cell Mol Biol. 2010; 43: 259-268.

[38]Beeh KM, Beier J, Esperester A, Paul LD. Antiinflammatory properties of ambroxol. Eur J Med Res. 2008; 13:557-562.

[39] Malerba M, Ragnoli B. Ambroxol in the 21st century: pharmacological and clinical update. Expert Opin Drug Metab Toxicol. 2008; 4:1119-1129.

[40]Ren Y, Yu C, Meng K, Tang X. Influence of formulation and preparation process on ambroxol hydrochloride dry powder inhalation characteristics and aerosolization properties. Drug Dev Ind Pharm. 2008; 34:984-991.

[41]Ren YC, Wang L, He HB, Tang X. Pulmonary selectivity and local pharmacokinetics of ambroxol hydrochloride dry powder inhalation in rat. $\mathrm{J}$ Pharm Sci. 2009; 98:1797-1803. 
[42] Mezetti M, Colombo L, Marini MG, Crusi, P. Pierfederici, and E. Mussini. A pharmacokinetic study on pulmonary tropism of ambroxol in patients under thoracic surgery. J Emerg Surg Intensive Care. 1990; 13:179-185.

[43]Leach CL, Davidson PJ, Boudreau RJ. Improved airway targeting with the CFC-free HFA-beclomethasone metered-dose inhaler compared with CFC-beclomethasone. Eur Respir J. 1998; 12:1346-1353.

[44]Leikauf GD, Borchers MT, Prows DR, Simpson LG. Mucin apoprotein expression in COPD. Chest. 2002;121(5 Suppl):166S-182S.

[45]Caramori G, Di Gregorio C, Carlstedt I, Casolari P, Guzzinati I, Adcock IM, Barnes PJ, Ciaccia A, Cavallesco G, Chung KF, Papi A. Mucin expression in peripheral airways of patients with chronic obstructive pulmonary disease. Histopathology 2004; 45: 477-484.

[46]Houtmeyers E, Gosselink R, Gayan-Ramirez G, Decramer M. Effects of drugs on mucus clearance. Eur Respir J 1999; 14: 452-467

[47]Rogers DF. The role of airway secretions in COPD: pathophysiology, epidemiology and pharmacotherapeutic options. COPD: J Chron Obstructive Pulm Dis 2005; 2: 341-353.

[48]Rogers DF, Barnes PJ. Treatment of airway mucus hypersecretion. Ann Med.2006; 38(2):116-125.

[49]Mercer BA, Kolesnikova N, Sonett J, D'Armiento J. Extracellular regulated kinase/mitogen activated protein kinase is up-regulated in pulmonary emphysema and mediates matrix metalloproteinase-1 induction by cigarette smoke. J Biol Chem. 2004; 279:17690-17696.

[50]Zhang W, Yan SD, Zhu A, Zou YS, Williams M, Godman GC, Thomashow BM, Ginsburg ME, Stern DM, Yan SF. Expression of Egr-1 in late stage emphysema. Am J Pathol. 2000; 157:1311-1320.

[51]Chen BC, Yu CC, Lei HC, Chang MS, Hsu MJ, Huang CL, Chen MC, Sheu JR, Chen TF, Chen TL, Inoue H, Lin CH. Bradykinin B2 receptor mediates NF-kappaB activation and cyclooxygenase-2 expression via the Ras/Raf-1/ERK pathway in human airway epithelial cells. J Immunol. 2004;173:5219-28. 
[52]Tuyt LM, Dokter WH, Birkenkamp K, Koopmans SB, Lummen C, Kruijer W, Vellenga E. Extracellular-regulated kinase 1/2, Jun N-terminal kinase, and c-Jun are involved in NF-kappa B-dependent IL-6 expression in human monocytes. J Immunol.1999; 162:4893-4902. 


\section{Figure Legends}

Fig.1. Ambroxol decreases inflammation in the CS-induced lung injuries. Mice were repeatedly exposed to CS for $4 \mathrm{~d}$. Then, they were treated with Amb $(1.875,3.75$, or $7.5 \mathrm{mg} / \mathrm{ml}$ ) for $20 \mathrm{~min}$ with a jet nebulizer (BARI Co. Ltd., Germany) (i.h) $10 \mathrm{~min}$ before daily CS exposure. Amb hydrochloride at $20 \mathrm{mg} / \mathrm{kg}$ was intravenously injected $10 \mathrm{~min}$ before the mice were exposed to cigarettes. Dexamethasone sodium phosphate at $0.5 \mathrm{mg} / \mathrm{kg}$ was intraperitoneally injected into mice $1 \mathrm{~h}$ before their exposure to cigarettes. Control and model mice received solvent inhalation. (A) The total inflammatory cells in the BALFs were counted. At least 200 cells were used to classify inflammatory cells as neutrophils, macrophages, and lymphocytes. (B) Lung tissues were stained with H\&E. Representative images from three independent experiments are shown. Inflammatory cells were observed under microscopes. Mice with air exposure had no infiltration of inflammatory cells (Control). CS exposure induced an influx of macrophages (green arrowheads), neutrophils (black arrowheads) and lymphocytes (red arrowheads) into the alveolar spaces. (C) To determine the severity of inflammatory cells infiltration in the alveolar spaces, cell count was performed based on a 5-point scoring system described previously [32, 33]. Data are presented as mean \pm SEM, $\mathrm{n}=10$. Scale bar, $20 \mu \mathrm{m}$. \#p $<0.05$, \#\#p $<0.01$, \#\#\# $<$ 0.001 compared with control. $* \mathrm{p}<0.05 . * * \mathrm{p}<0.01, * * * \mathrm{p}<0.001$ compared with mice with CS exposure. $\uparrow \mathrm{p}<0.05$ compared with mice was intravenously injected with Amb at $20 \mathrm{mg} / \mathrm{kg}$.

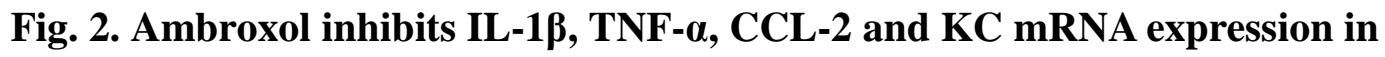
lung tissues and their protein levels in the BALF. Lung homogenates were prepared for analyzing mRNA expression $18 \mathrm{~h}$ after the final CS exposure. The BALF was also harvested and tested in the meantime. (A) IL-1 $\beta$, TNF- $\alpha$, CCL-2 and KC mRNA levels in lung tissues and (B) protein levels in the BALF are shown. Data are presented as mean \pm SEM, $\mathrm{n}=10$. \#p $<0.05$, \#\#p $<0.01$, \#\#\# $<0.001$ compared with control. $* \mathrm{p}<0.05 . * * \mathrm{p}<0.01, * * * \mathrm{p}<0.001$, compared with mice with CS alone 
exposure (model). $† p<0.05$ compared with mice was intravenously injected with Amb at $20 \mathrm{mg} / \mathrm{kg}$.

Fig. 3. Ambroxol reduces glycosaminoglycans levels and MUC5AC expression. To measure glycosaminoglycans levels, and MUC5AC mRNA and protein expression in vivo, the BALF and the lung tissues were harvested and tested $18 \mathrm{~h}$ after the final CS exposure. (A) glycosaminoglycans levels in the BALF are shown; (B and C) MUC5AC mRNA expression in lung tissues and its protein levels in the BALF. Data are presented as mean $\pm \mathrm{SEM}, \mathrm{n}=10$. \#\#\#p $<0.001$ compared with control. $* \mathrm{p}<0.05$. $* * \mathrm{p}<0.01, * * * \mathrm{p}<0.001$, compared with mice exposed to CS alone (model).

Fig. 4. Ambroxol reduces the CSE-induced IL-1 $\beta$, TNF- $\alpha$ and MUC5AC mRNA expression in pulmonary epithelial cells. To examine the effects of CSE on IL-1 $\beta$, TNF- $\alpha$ and MUC5AC mRNA expression in lung epithelia, NCI-H292 cells were pretreated with Amb $(0.2,2$ or $20 \mu \mathrm{M})$ or $\mathrm{U} 0126(10 \mu \mathrm{M})$ for $15 \mathrm{~min}$; then the cells were treated with CSE (2.5\%) for $24 \mathrm{~h}$. The culture supernatants were measured for IL-1 $\beta$, TNF- $\alpha$ and MUC5AC mRNA levels using Q-PCR. The effects of CSE exposure at various concentrations or for various time duration on IL- $1 \beta$, TNF- $\alpha$ and MUC5AC mRNA expression are shown (A and B). Treatment with Amb at $20 \mu \mathrm{M}$ significantly decreases CSE-mediated IL-1 $\beta$, TNF- $\alpha$ and MUC5AC mRNA expression $(\mathrm{C})$. Data are presented as mean $\pm \mathrm{SEM}, \mathrm{n}=5$. \#p $<0.05$, \#\#p $<0.01$, \#\#\# $<0.001$ compared with control. $* \mathrm{p}<0.05 . * * \mathrm{p}<0.01, * * * \mathrm{p}<0.001$ compared with the cells exposed to CSE alone.

Fig.5. Ambroxol reduces the CSE-induced inflammatory factors and MUC5AC expression by inhibiting the activity of Erk1/2 in pulmonary epithelial cells. CSE (2.5\%) time-dependently activates Erk and P38 signaling in NCI-H292 cells. The activity of Erk1/2 and P38 was determined in the indicated cell line by immunoblotting. Amb $20 \mu \mathrm{M}$ significantly reduces the CSE-induced activation of 
ERK (A), but not P38 (B) in pulmonary epithelial cells. The pharmacological inhibition with an ERK inhibitor U0126 at $10 \mu \mathrm{M}$ significantly decreases CSE-mediated IL-1 $\beta$, TNF- $\alpha$ and MUC5AC mRNA expression (C). Data are expressed as mean $\pm \mathrm{SEM}, \mathrm{n}=5$. \# $\mathrm{p}<0.05$, \#\# $<0.01$ compared with control. $* \mathrm{p}<$ $0.05 . * * \mathrm{p}<0.01, * * * \mathrm{p}<0.001$ compared with cells exposed to CSE alone. 
Table 1. Primer sequences for measuring mRNAs using real-time PCR (The sequences are listed from 5 ' to 3').

\begin{tabular}{|c|c|}
\hline Genes & Primer sequences ( 5'-3') \\
\hline \multirow{2}{*}{ Mouse TNF- $\alpha$} & F: CAAGGGACAAGGCTGCCCCG \\
\hline & R: GCAGGGGCTCTTGACGGCAG \\
\hline \multirow{2}{*}{ Mouse IL-1 $\beta$} & F: GCTTCAGGCAGGCAGTAT \\
\hline & R: ACAAACCGCTTTTCCATCT \\
\hline \multirow{2}{*}{ Mouse CCL-2 } & F: AGGTCCCTGTCATGCTTCTGG \\
\hline & R: TGCTGCTGGTGATCCTCTTGT \\
\hline \multirow{2}{*}{ Mouse KC } & F: GCTGGGATTCACCTCAAGAA \\
\hline & R: TGGGGACAAATTTTAGCATC \\
\hline \multirow{2}{*}{ Mouse MUC5AC } & F: ACATTTCCCCATGCTCCACAGC \\
\hline & R: GTGGTGGTATTAGACTCCTGG \\
\hline \multirow{2}{*}{ Mouse $\beta$-actin } & F: GTATGGTCG TGGCTCTAAGC \\
\hline & R: ATGTCACGCACGATTTCC \\
\hline \multirow{2}{*}{ Human TNF- $\alpha$} & F: ATCTATCTGGGAGGGGTCTTCC \\
\hline & R: AGAGGTTGAGGGTGTCTGAAGG \\
\hline \multirow{2}{*}{ Human IL-1 $\beta$} & F:ATCAGCCAGGACAGTCAG \\
\hline & R:CAGTAAGCGAGGGTGTAAG \\
\hline \multirow{2}{*}{ Huma MUC5AC } & F: GGGACAAGGAAACCTACAACA \\
\hline & R: GACAGGGAAGGATACAGAGCA \\
\hline \multirow{2}{*}{ Human GAPDH } & F: GAAGGTGAAGGTCGGAGTC \\
\hline & R: GAAGATGGTGATGGGATTTC \\
\hline
\end{tabular}




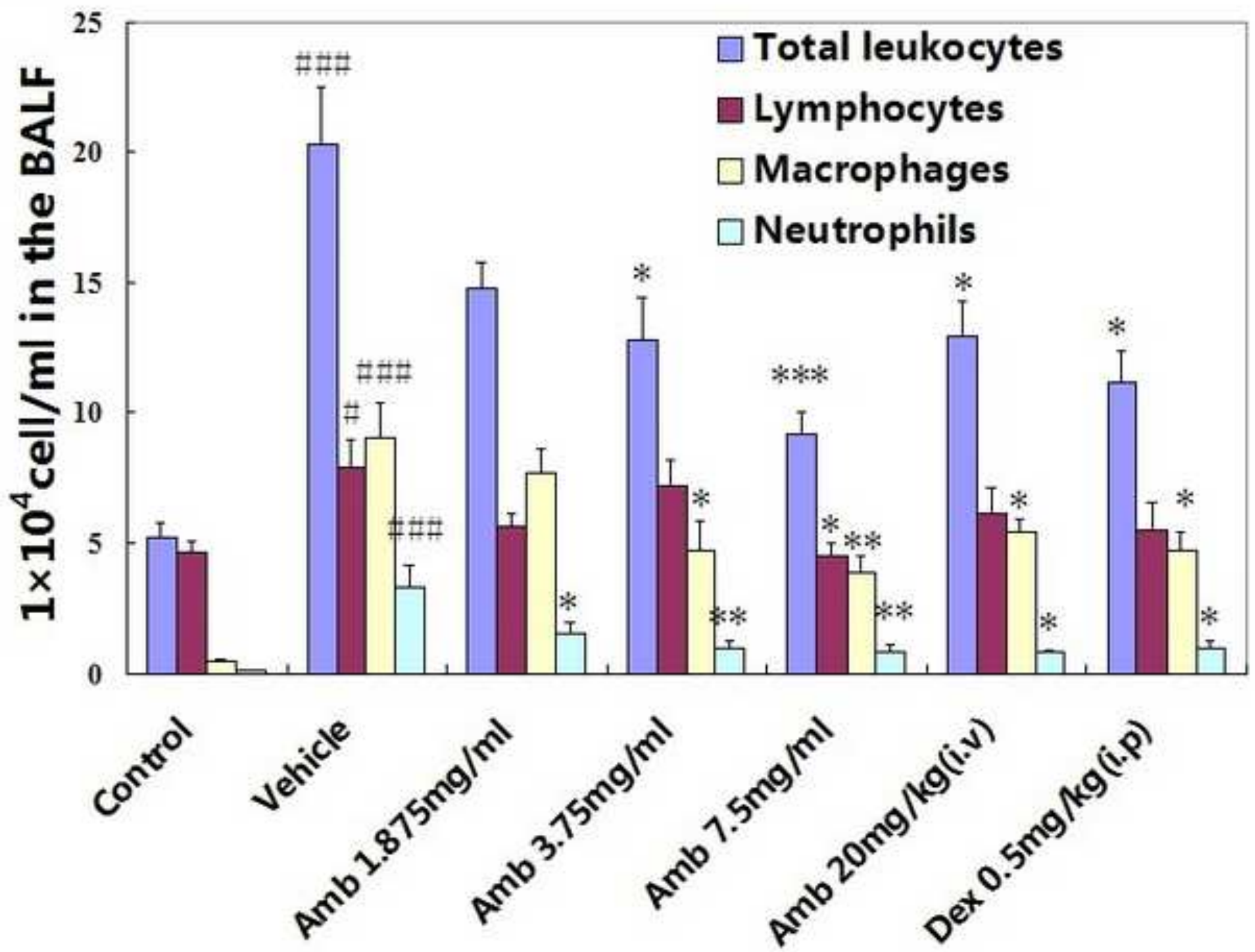




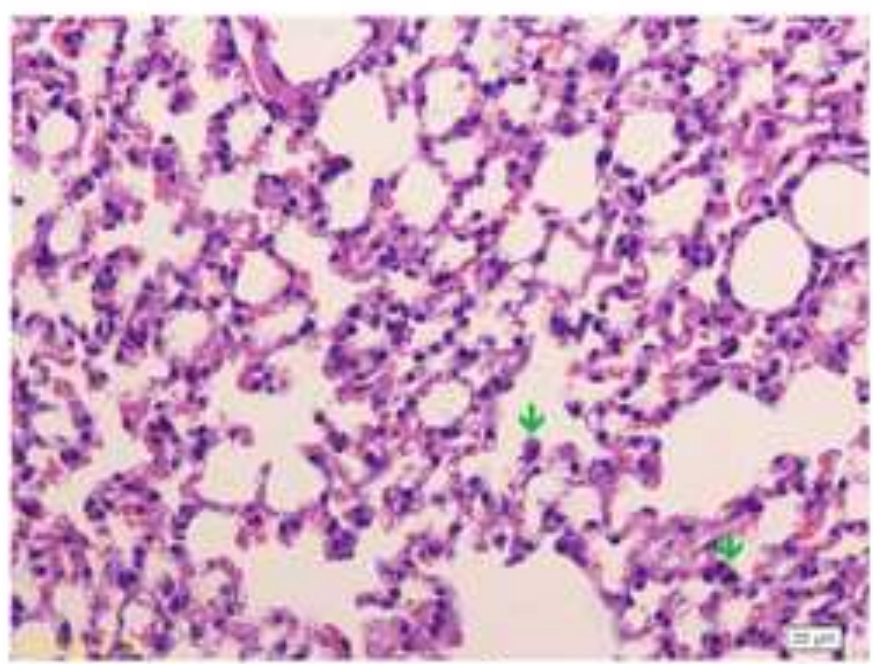

\section{Control}

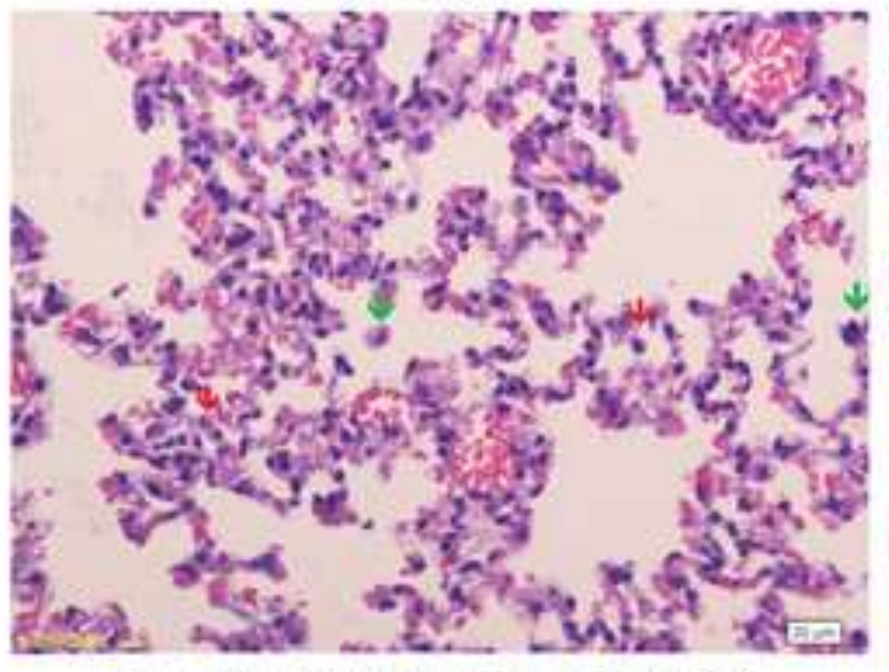

\section{Ambroxl 75 mg/ml (i.h.)}

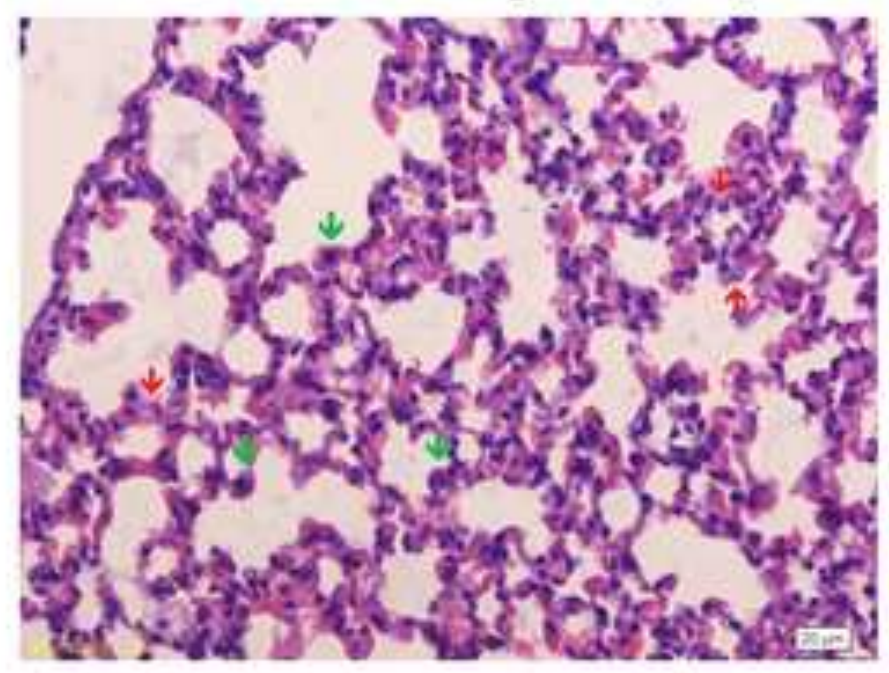

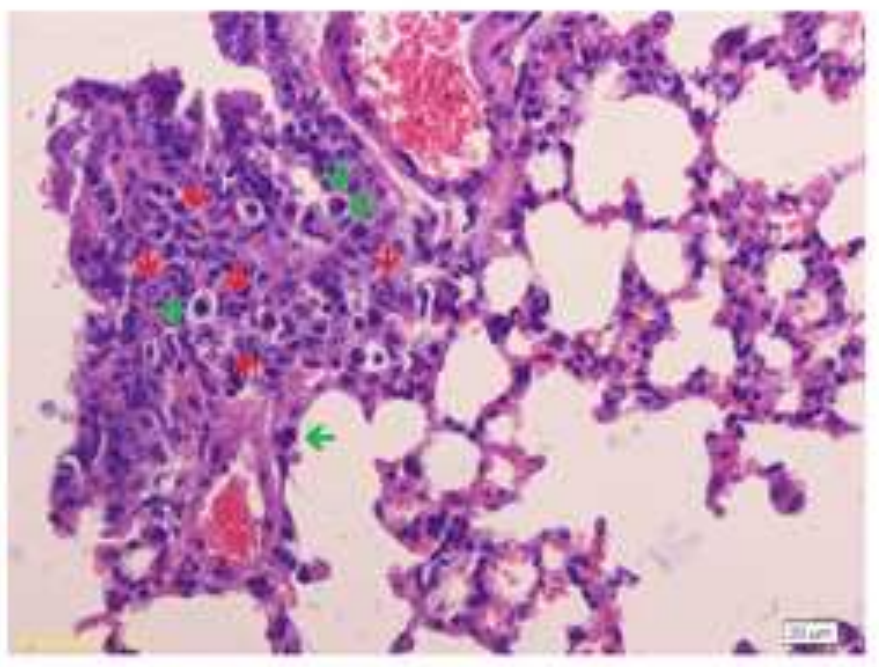

\section{Vehicle}

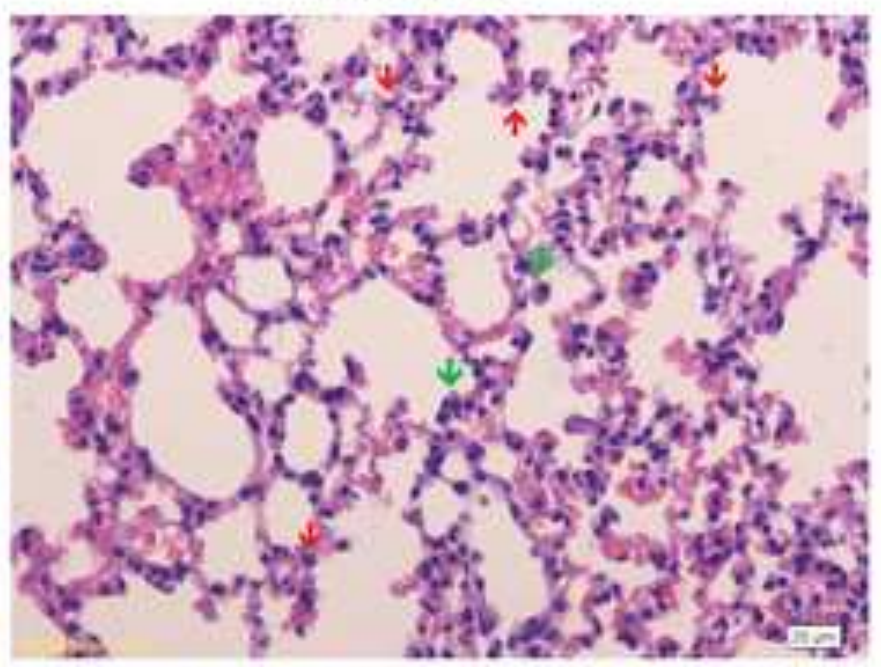

Ambroxol $20 \mathrm{mg} / \mathrm{kg}$ (i.v.)

Dexamethasone $0.5 \mathrm{mg} / \mathrm{kg}$ (i.p.) 


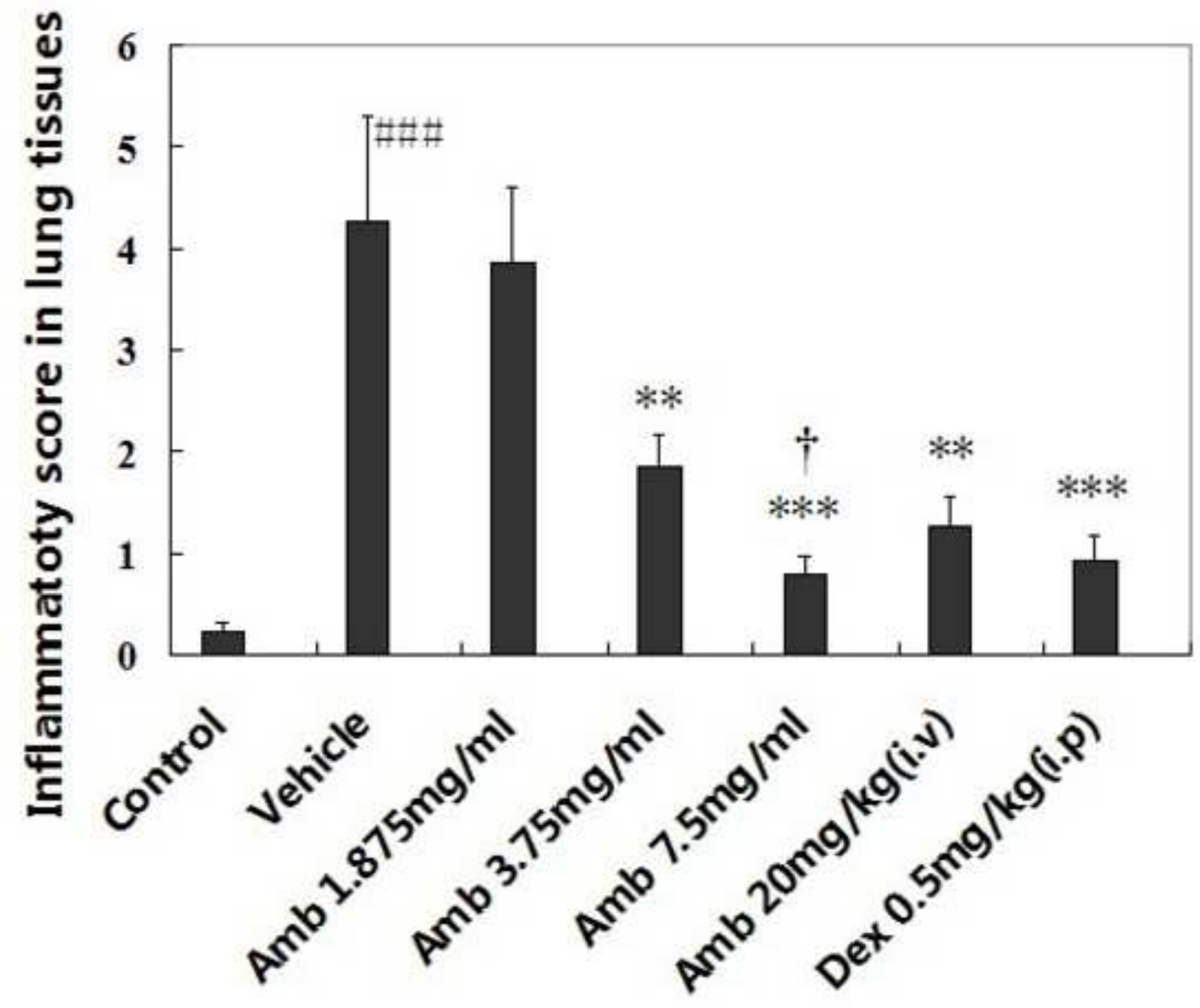




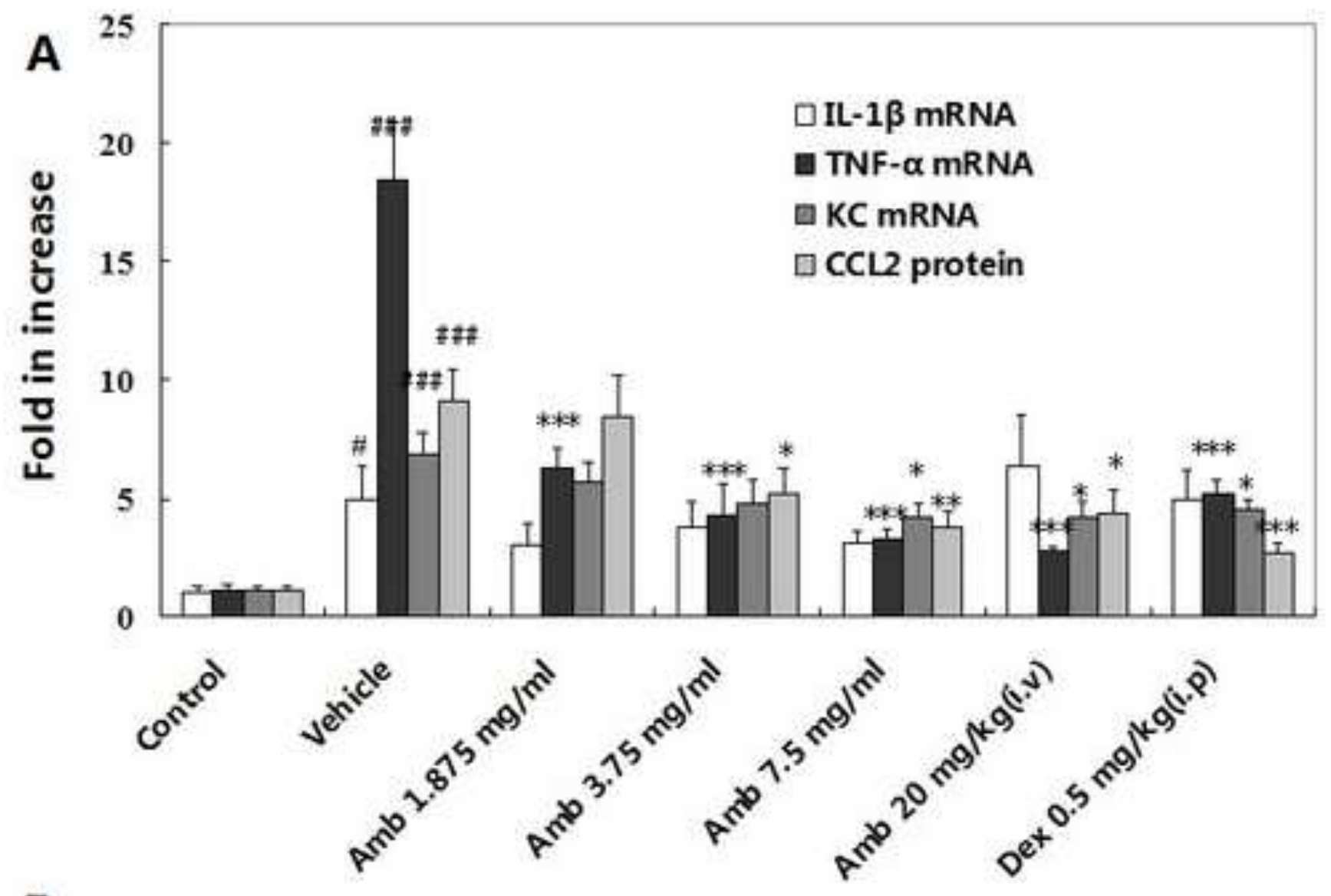

B

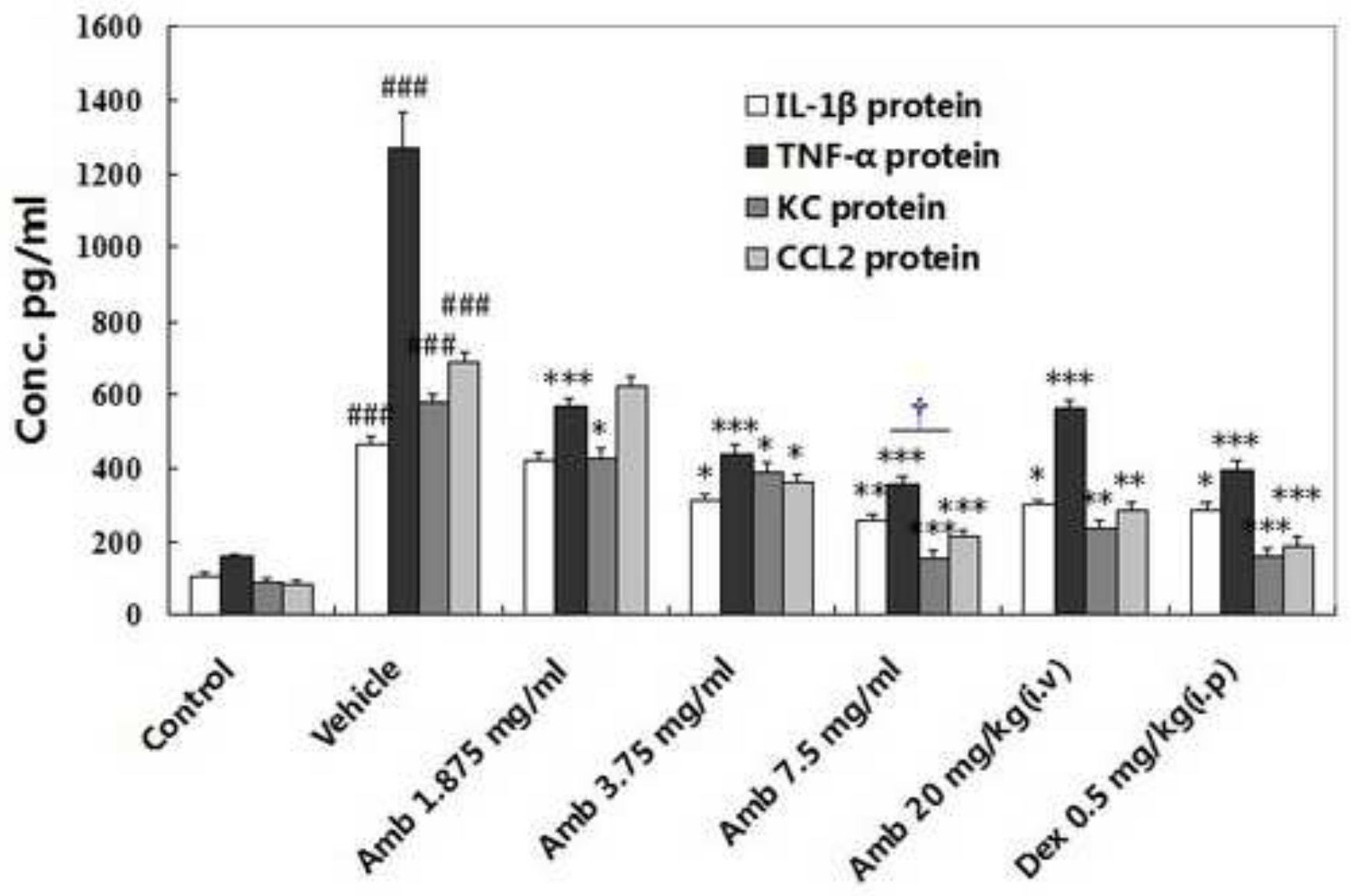



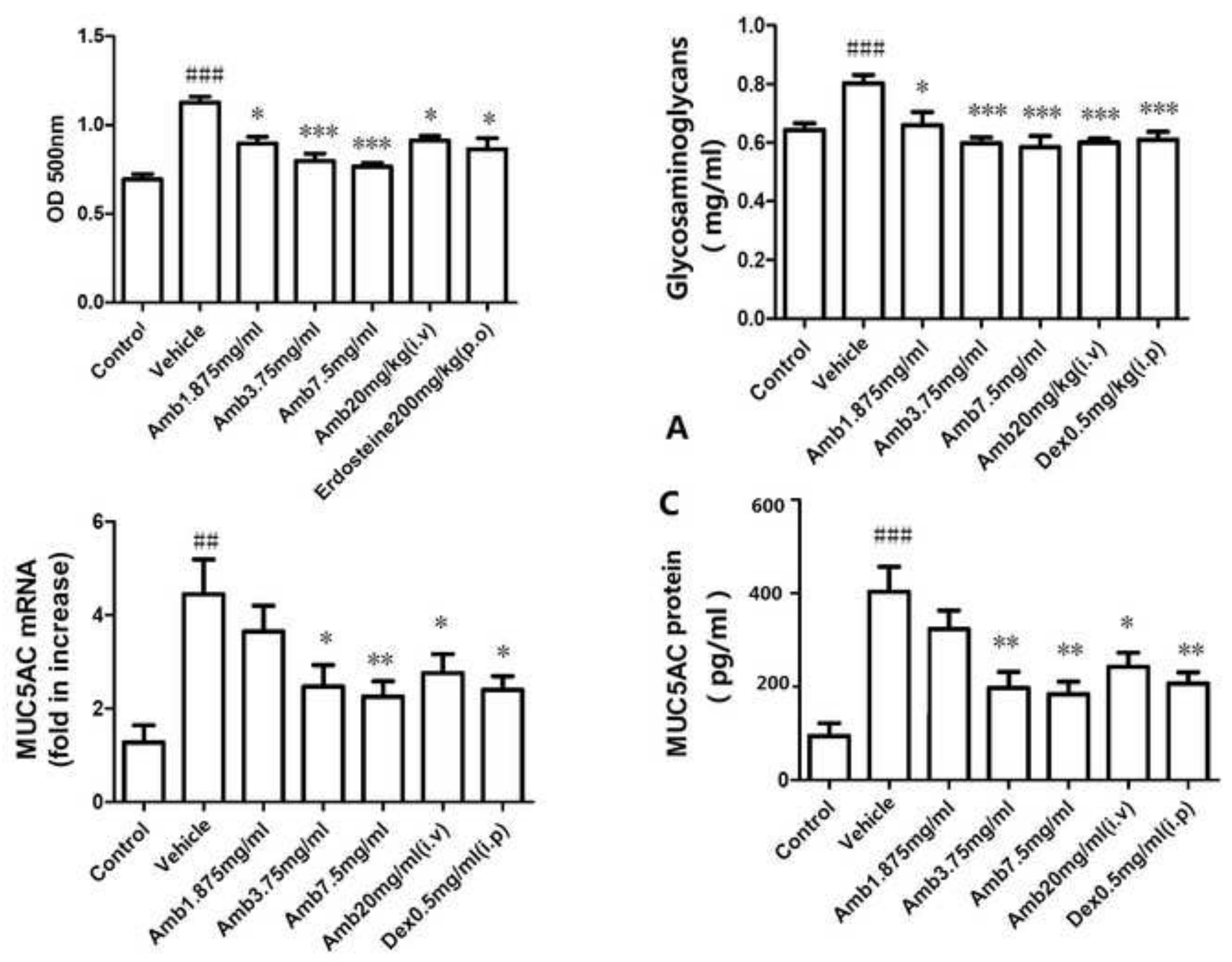

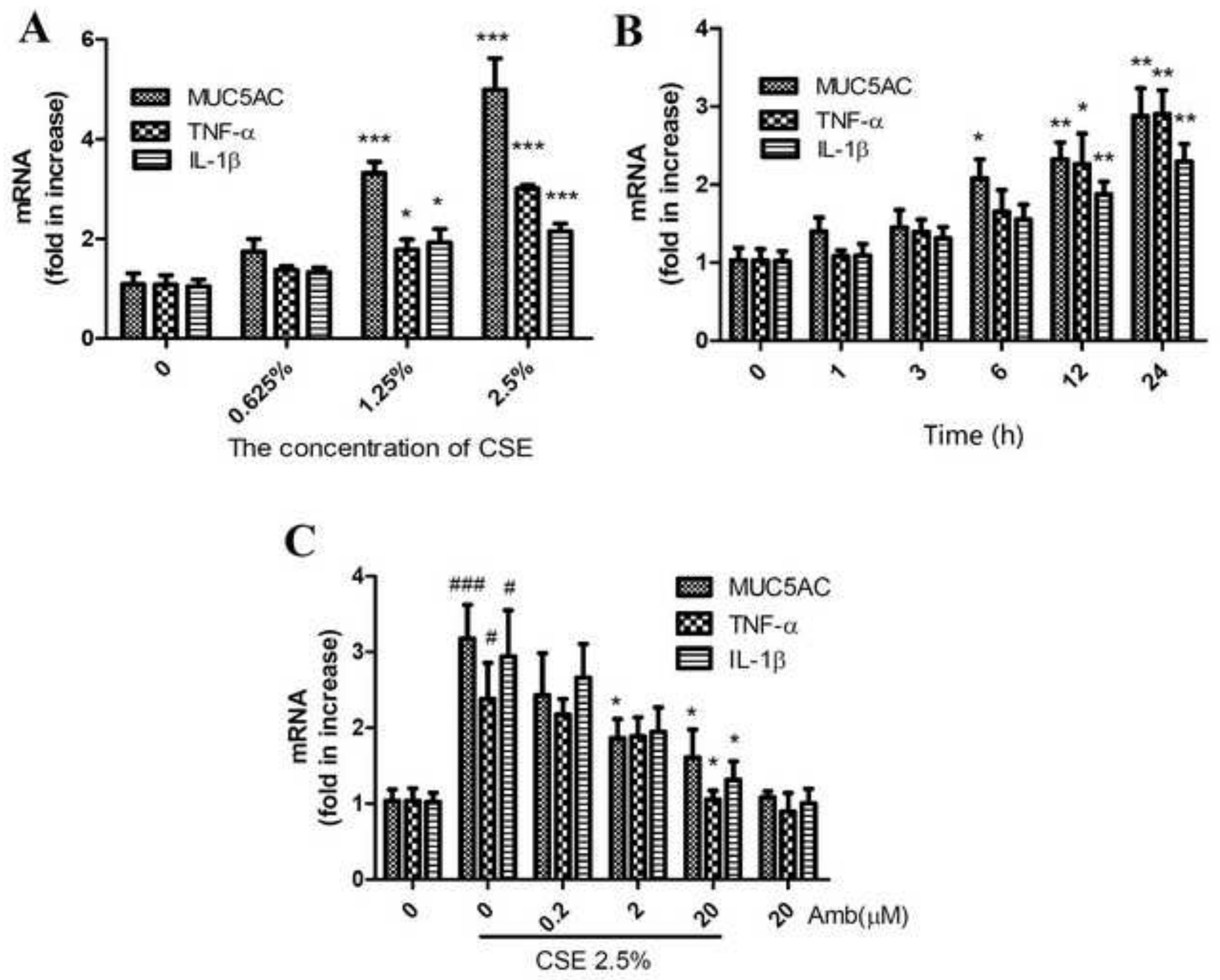

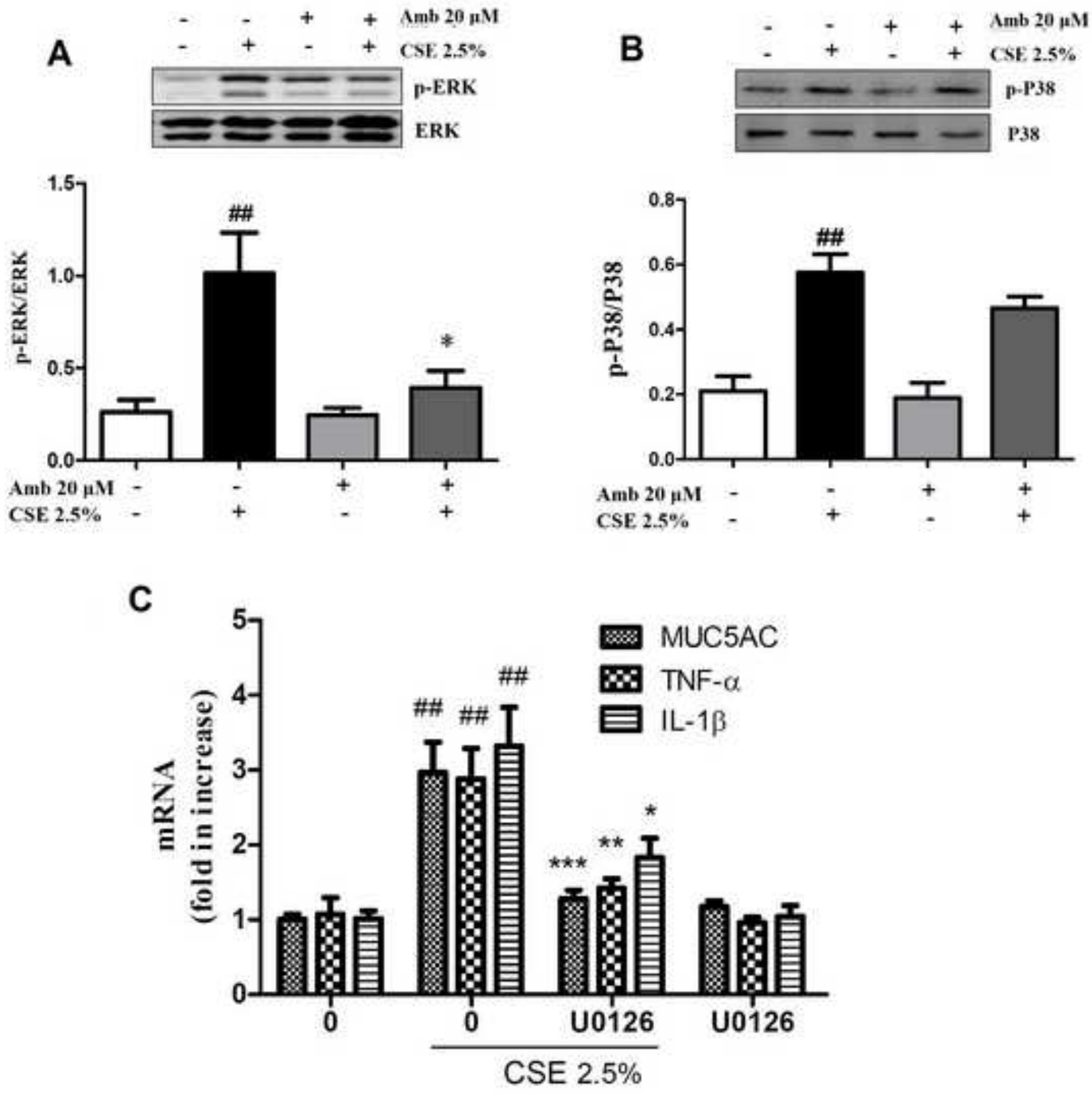